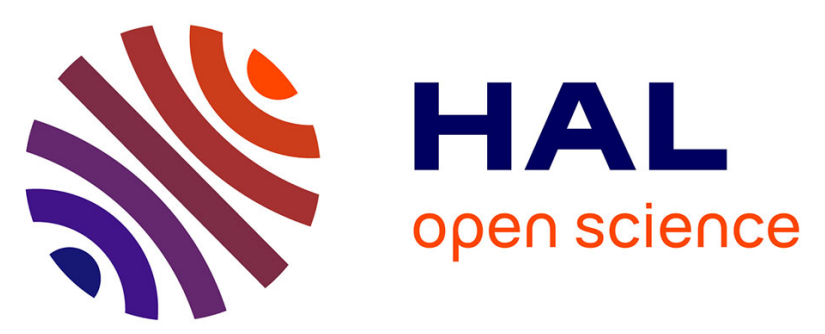

\title{
Assessment of reference evapotranspiration methods in semi-arid regions: can weather forecast data be used as alternate of ground meteorological parameters?
}

S. Er-Raki, Ghani Chehbouni, S. Khabba, Vincent Simonneaux, Lionel Jarlan, A. Ouldbba, J. C. Rodriguez, R. Allen

\section{To cite this version:}

S. Er-Raki, Ghani Chehbouni, S. Khabba, Vincent Simonneaux, Lionel Jarlan, et al.. Assessment of reference evapotranspiration methods in semi-arid regions: can weather forecast data be used as alternate of ground meteorological parameters?. Journal of Arid Environments, 2010, 74 (12), pp.1587-1596. 10.1016/j.jaridenv.2010.07.002 . ird-00610374

\section{HAL Id: ird-00610374 https://hal.ird.fr/ird-00610374}

Submitted on 5 Oct 2011

HAL is a multi-disciplinary open access archive for the deposit and dissemination of scientific research documents, whether they are published or not. The documents may come from teaching and research institutions in France or abroad, or from public or private research centers.
L'archive ouverte pluridisciplinaire HAL, est destinée au dépôt et à la diffusion de documents scientifiques de niveau recherche, publiés ou non, émanant des établissements d'enseignement et de recherche français ou étrangers, des laboratoires publics ou privés. 


\title{
Assessment of reference evapotranspiration methods in semi-arid regions: Can weather forecast data be used as alternate of ground meteorological parameters?
}

\author{
S. Er-Raki a, ${ }^{\text {a }}$, A. Chehbouni ${ }^{\text {b }}$, S. Khabba ${ }^{\text {a }}$, V. Simonneaux ${ }^{\text {b }}$, L. Jarlan ${ }^{\text {b,c }}$, A. Ouldbba ${ }^{c}$, J.C. Rodriguez ${ }^{\text {, }}$ \\ R. Allen ${ }^{\mathrm{e}}$ \\ ${ }^{a}$ Cadi Ayyad University/IRD, Avenue Prince Moulay Abdellah, BP 2390, Marrakech 40000, Morocco \\ ${ }^{\mathrm{b}}$ CESBIO - Centre d'Etudes Spatiales de la Biosphère, 18 Avenue Edouard Belin, bpi 2801, 31401 Toulouse Cedex 9, France \\ ${ }^{\mathrm{c}} \mathrm{DMN}$ : Direction de la Météorologie Nationale, Casablanca, Morocco \\ ${ }^{\mathrm{d}}$ Universidad de Sonora, Hermosillo, Mexico \\ ${ }^{\mathrm{e}}$ Water Resources Engineering, University of Idaho, 3793 N. 3600 E., Kimberly, ID 83341, USA
}

\section{A R T I C L E I N F O}

Article history:

Received 8 February 2010

Received in revised form

12 July 2010

Accepted 21 July 2010

Available online $\mathrm{xxx}$

Keywords:

ALADIN model

Reference evapotranspiration

Semi-arid environment

\section{Introduction}

The Food and Agriculture Organization (FAO) recommends the use of the FAO Penman-Monteith (FAO-PM) equation for estimating reference evapotranspiration $\left(\mathrm{ET}_{0}\right)$ (Allen et al., 1998, 2006). This method is the most widely used in the world, and has been proven to accurately estimate $\mathrm{ET}_{0}$ in different climates (Allen et al., 1998; De Bruin and Stricker, 2000; Hussein and AlGhobari, 2000; Kashyap and Panda, 2001; Smith, 2000; Walter et al., 2000). However, it requires several measurements of climatic variables such as air temperature, relative humidity, solar radiation and wind speed. Unfortunately, there are a limited number of sites over the world where complete meteorological

* Corresponding author at: Projet SudMed, Centre Geber salle 26, Faculty of Science Semlalia, Cadi Ayyad University, BP 2390, Marrakech, Morocco. Tel./fax: +212 (0) 524431626 . :

E-mail addresses: s.erraki@ucam.ac.ma, s.erraki@gmail.com (S. Er-Raki). stations are installed for routine measurements of these climatic variables. This lack of meteorological data leads to the development of simpler approaches to estimate $\mathrm{ET}_{0}$ that require only a few climatic parameters. In this context, several methods have been reported in the literature to estimate $\mathrm{ET}_{0}$. Some of these methods are based on a single climatic variable, i.e., solar radiation (Blaney and Criddle, 1950; Makkink, 1957; Priestley and Taylor, 1972) or temperature (Hargreaves and Samani, 1985). Other methods are based on different combinations of climatic parameters involving solar radiation, air temperature, humidity and wind speed (Allen et al., 1998; Doorenbos and Pruitt, 1977; Monteith, 1965; Penman, 1948). When air temperature is the only available variable, Allen et al. (1998) proposed the use of the Hargreaves-Samani (HARG) equation (Hargreaves and Samani, 1985 ) as an alternative to estimate $\mathrm{ET}_{0}$. In this regard, several studies have shown that this equation may provide reasonable estimates of $\mathrm{ET}_{0}$ (Choisnel et al., 1992; Dinpashoh, 2006; Droogers and Allen, 2002; Hargreaves, 1994; Henggeler et al., 1996; Jensen et al., 1990; Martınez-Cob and Tejero-Juste 2004). Other authors have reported that the HARG equation tends to overestimate $\mathrm{ET}_{0}$ 
in humid regions and to underestimate it in very dry regions (Amatya et al., 1995; Droogers and Allen, 2002; Jensen et al., 1990; Saeed, 1986; Xu and Singh, 2002). Therefore, the HARG equation may require local calibration prior to its application (Dinpashoh, 2006; Jensen et al., 1997; Vanderlinden et al., 1999; Xu and Singh, 2002). Makkink (1957) and Priestley and Taylor (1972) proposed two empirical equations for calculating $\mathrm{ET}_{0}$ when air temperature and solar radiation data are available. The PT equation is used in many crop models (e.g. CERES model (Ritchie, 1985); EPIC (Williams et al., 1989), SWAP (Utset et al., 2004)). Similarly, several studies have shown that this method underestimated $\mathrm{ET}_{0}$ in dry and windy conditions (Benson et al., 1992; Dugas and Ainsworth, 1983; Martınez-Cob, 2002).

When reliable climatic data are scarce or do no exist, an alternative approach might be to use data generated with numerical weather prediction models. These data present two advantages: i) they are becoming more and more available through the Internet; ii) the models provide spatially distributed data, which are very relevant to the regional scale studies. Unfortunately, there are two drawbacks associated with using this type of data. The first is that, the lowest atmospheric model layer is usually situated considerably higher than the reference height recommended for climatic measurements. Secondly, the spatial resolution of these models is very coarse. For example the ARPEGE global model of Meteorological France (Déqué et al., 1994; http:// www.cnrm.meteo.fr/gmgec/arpege/arpege.html) provides the data at a resolution of $20 \mathrm{~km}$ in France to $250 \mathrm{~km}$ in antipodes. The local model (ALADIN: Aire Limitée, Adaptation Dynamique, développement InterNational) of the Moroccan Meteorological Agency runs with a slightly higher spatial resolution $(16.7 \mathrm{~km})$ over Morocco.

The objective of this study is (1) to evaluate, under semi-arid conditions, the performance of three empirical methods (PT, Mak and HARG) for estimating $\mathrm{ET}_{0}$ by comparing their values to those estimated using the FAO-PM equation and (2) to evaluate the potentiality of weather forecast prediction as an alternative to measured climatic data.

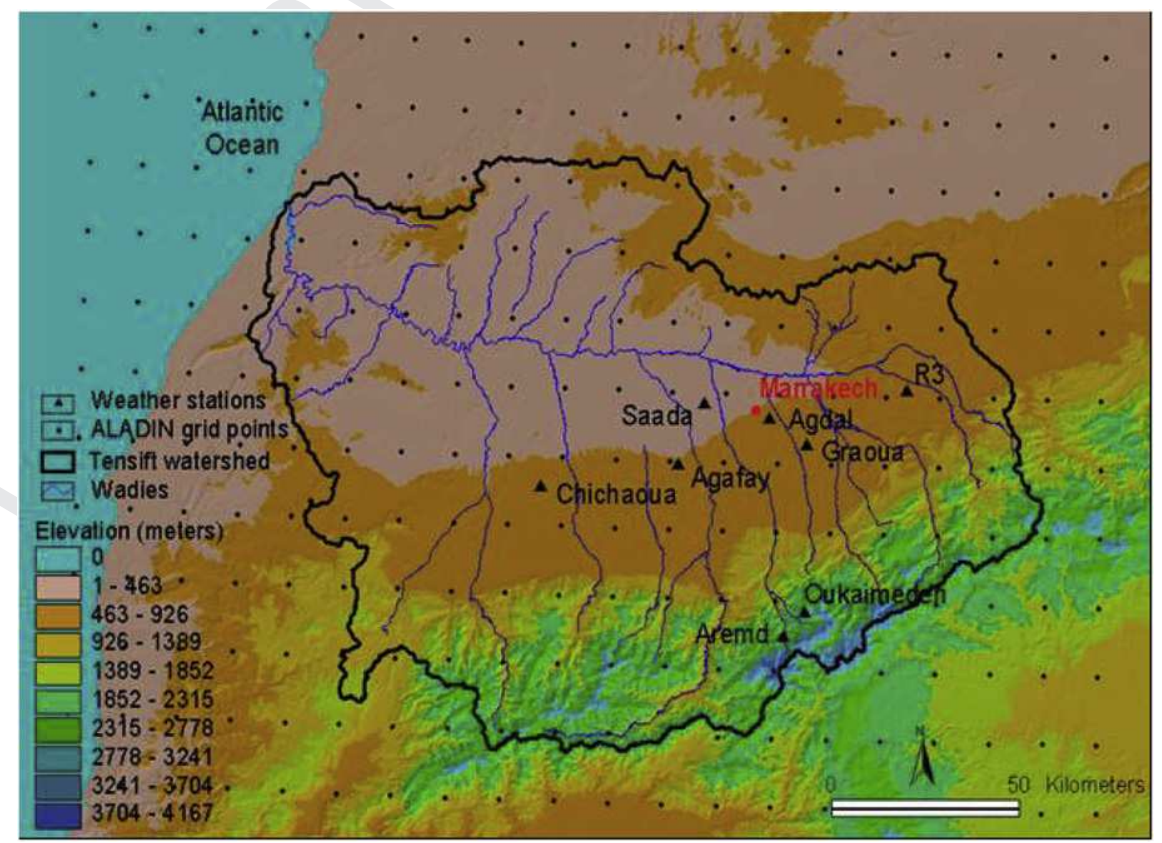

\section{Materials and methods}

\subsection{Area description and weather data}

The three empirical methods (Eqs. (2)-(4)) were evaluated over two sites described below (the Tensift region around Marrakech, Morocco and the Yaqui Valley in the north of Mexico) against the FAOPM method. In addition, a weather forecast model (ALADIN) available over the Tensift basin was used to estimate the spatial-temporal distribution of $\mathrm{ET}_{0}$.

\subsubsection{Tensift basin}

The Tensift basin situated in central of Morocco is located between $30.75^{\circ}-32.40^{\circ} \mathrm{N}$ and $7.05^{\circ}-9.9^{\circ} \mathrm{W}$, occupying an expanse around $30000 \mathrm{~km}^{2}$. The climate is semi-arid, typically Mediterranean; with an average annual precipitation of about $250 \mathrm{~mm}$. Air temperature is very high in summer $\left(38^{\circ} \mathrm{C}\right)$ and low in winter $\left(5^{\circ} \mathrm{C}\right)$. The mean annual value for $\mathrm{ET}_{0}$, calculated using the $\mathrm{FAO}-\mathrm{PM}$ equation, is about $1600 \mathrm{~mm}$ (Allen et al., 1998). In the Tensift basin, a large area is dedicated to agriculture. The Haouz plain covers around $6000 \mathrm{~km}^{2}$, and is delimited to the north by the 'Jbilet' hills and to the south by the High-Atlas mountain range (that culminates up to $4000 \mathrm{~m}$ ). Weather data sets were obtained from the 8 stations installed in the framework of the SudMed project (Chehbouni et al., 2008) (see Fig. 1). Locations of the stations are given in Table 1. In addition, the aridity index defined as the ratio of the annual rainfall to the annual $\mathrm{ET}_{0}$ (UNEP, 1997) is calculated for each Tensift stations. Each station measures with a $30 \mathrm{~min}$ time step and at a $2 \mathrm{~m}$ height: air temperature, relative humidity, solar radiation, wind speed and direction and rainfall. In some stations (Agdal, Saada and Agafay), net radiation $\left(R_{\mathrm{n}}\right)$ was measured with a Kipp and Zonen CNR1 net radiometer. The daily values of the meteorological variables were used to compute daily $\mathrm{ET}_{0}$. The network stations were deployed in order to cover the spatial variability of the climate over the whole Tensift basin. Based on the calculated aridity index (Table 1) during 2004, the Tensift area can be divided into two distinct climatic regions. The first one situated in the Haouz plain characterized by
Fig. 1. Study area and location of the weather stations. 
Table 1

Weather stations used in the study.

\begin{tabular}{|c|c|c|c|c|c|c|}
\hline Station & Latitude (degrees) ${ }^{\mathrm{a}}$ & Longitude (degrees) ${ }^{a}$ & Elevation (m) & Surface & Aridity index ${ }^{b}$ & Climate \\
\hline Agdal & $31^{\circ} 60^{\prime} 11^{\prime \prime} \mathrm{N}$ & $7^{\circ} 97^{\prime} 38^{\prime \prime} \mathrm{W}$ & 506 & Olives & 0.2 & Semi-arid \\
\hline Agafay & $31^{\circ} 50^{\prime} 27^{\prime \prime} \mathrm{N}$ & $8^{\circ} 25^{\prime} 02^{\prime \prime} \mathrm{W}$ & 479 & Grass & 0.18 & Semi-arid \\
\hline Chichawa & $31^{\circ} 44^{\prime} 92^{\prime \prime} \mathrm{N}$ & $8^{\circ} 63^{\prime} 75^{\prime \prime} \mathrm{W}$ & 517 & Bare soil $^{\mathrm{c}}$ & 0.09 & Semi-arid \\
\hline Graoua & $31^{\circ} 58^{\prime} 73^{\prime \prime} \mathrm{N}$ & $7^{\circ} 92^{\prime} 07^{\prime \prime} \mathrm{W}$ & 523 & Grape & 0.12 & Semi-arid \\
\hline Saada & $31^{\circ} 62^{\prime} 73^{\prime \prime} \mathrm{N}$ & $8^{\circ} 16^{\prime} 56^{\prime \prime} \mathrm{W}$ & 430 & Citrus & 0.19 & Semi-arid \\
\hline R3 & $31^{\circ} 66^{\prime} 74^{\prime \prime} \mathrm{N}$ & $7^{\circ} 59^{\prime} 57^{\prime \prime} \mathrm{W}$ & 593 & Bare soil $^{\mathrm{c}}$ & 0.16 & Semi-arid \\
\hline Okaimden & $31^{\circ} 12^{\prime} 42^{\prime \prime} \mathrm{N}$ & $7^{\circ} 86^{\prime} 28^{\prime \prime} \mathrm{W}$ & 3230 & Mountain $^{\mathrm{d}}$ & 0.53 & Sub-humid \\
\hline Armed & $31^{\circ} 60^{\prime} 11^{\prime \prime} \mathrm{N}$ & $7^{\circ} 92^{\prime} 07^{\prime \prime} \mathrm{W}$ & 2050 & Mountain $^{\mathrm{d}}$ & 0.40 & Sub-humid \\
\hline
\end{tabular}

a Degrees, minutes and seconds.

b The aridity index was calculated as the ratio of annual rainfall to annual $\mathrm{ET}_{0}$.

c Some natural vegetation may be present especially in the winter.

d The snow is present in the winter.

Q2 the semi-arid climate, in which all stations (Agdal, Agafay, Chichawa, Grawa, Saada and R3) have an aridity index less than 0.2. The second region located in the Atlas mountain range, characterized by the sub-humid conditions (Okaimden and Armed stations) where the aridity index was relatively higher (0.4-0.53).

Fig. 2 shows the daily evolution of the meteorological variables recorded by the station located in R3 zone (Table 1, Fig. 1) during 2003-2004. The mean annual solar radiation is about $17 \mathrm{MJ} / \mathrm{m}^{2}$ / day, and ranges between $4 \mathrm{MJ} / \mathrm{m}^{2} /$ day in December-January and $28 \mathrm{MJ} / \mathrm{m}^{2} /$ day in May-June. The seasonal variation of daily air temperature was similar - with respect to the shape - to that of solar radiation, between $5{ }^{\circ} \mathrm{C}$ in January and $36{ }^{\circ} \mathrm{C}$ in August, with an annual mean of about $18.5^{\circ} \mathrm{C}$. The evolution of relative humidity is out of phase with the solar radiation, and tends to increase in the winter and decrease in summer. Wind speed remained almost constant during the year around $2.1 \mathrm{~m} / \mathrm{s}$, but in some days its values exceeded $4 \mathrm{~m} / \mathrm{s}$. The cumulative precipitation during 2003 was $530 \mathrm{~mm}$ with most rain falling in the autumn and winter seasons. Note that this year was wetter in comparison with the average annual precipitation $(250 \mathrm{~mm})$. It should be mentioned that due to power supply problems, some data were missing during a few days.

\subsubsection{The forecasted climatic data from the ALADIN model (Morocco)}

When the meteorological parameters needed for estimating spatially $\mathrm{ET}_{0}$ are not available due to the scarcity of weather stations, it is possible to use the climatic data generated over a large area with the numerical weather prediction models. The numerical model used in this study is the ALADIN model adapted by the national meteorological services of Morocco (DMN) which generates all climatic parameters needed for $\mathrm{ET}_{0}$ estimate. ALADIN is a spectral model of numerical forecast in a limited area, based on the assimilation of daily measurements, and driven using the outputs of the ARPEGE global model (provided by French meteorological services). ARPEGE is an operational tool in the limited area modelling in Central Europe, and it is also used in several other regions (Morocco and Tunisia). The global model (ARPEGE) provides the data at resolution of $20 \mathrm{~km}$ in France to $250 \mathrm{~km}$ in antipodes, while the local model (ALADIN) is running at a higher spatial resolution $(16.7 \mathrm{~km})$ over Morocco. The ALADIN model over Morocco is named AL BACHIR and its main characteristics are:

- Spectral model with elliptical truncation.

- Horizontal resolution: $16.7 \mathrm{~km}$.

- Vertical resolution: 37 levels.

- Horizontal extent: $2000 \mathrm{~km} \times 2000 \mathrm{~km}(180 \times 180$ points $)$.

- Hydrostatic dynamic.
- Forecasting length: $72 \mathrm{~h}$.

- The model is run twice a day at $00 \mathrm{~h}$ and $12 \mathrm{~h}$.

- Outputs frequency: $03 \mathrm{~h}$.

The ALADIN model outputs include the climatic parameters (solar radiation, minimal and maximal air temperature, minimal and maximal relative humidity and wind speed) needed for $\mathrm{ET}_{0}$ estimate. The quality of this model, in generating weather variables, was evaluated by comparing the estimated climatic parameters with the ones measured over the Tensift basin. Importantly enough,
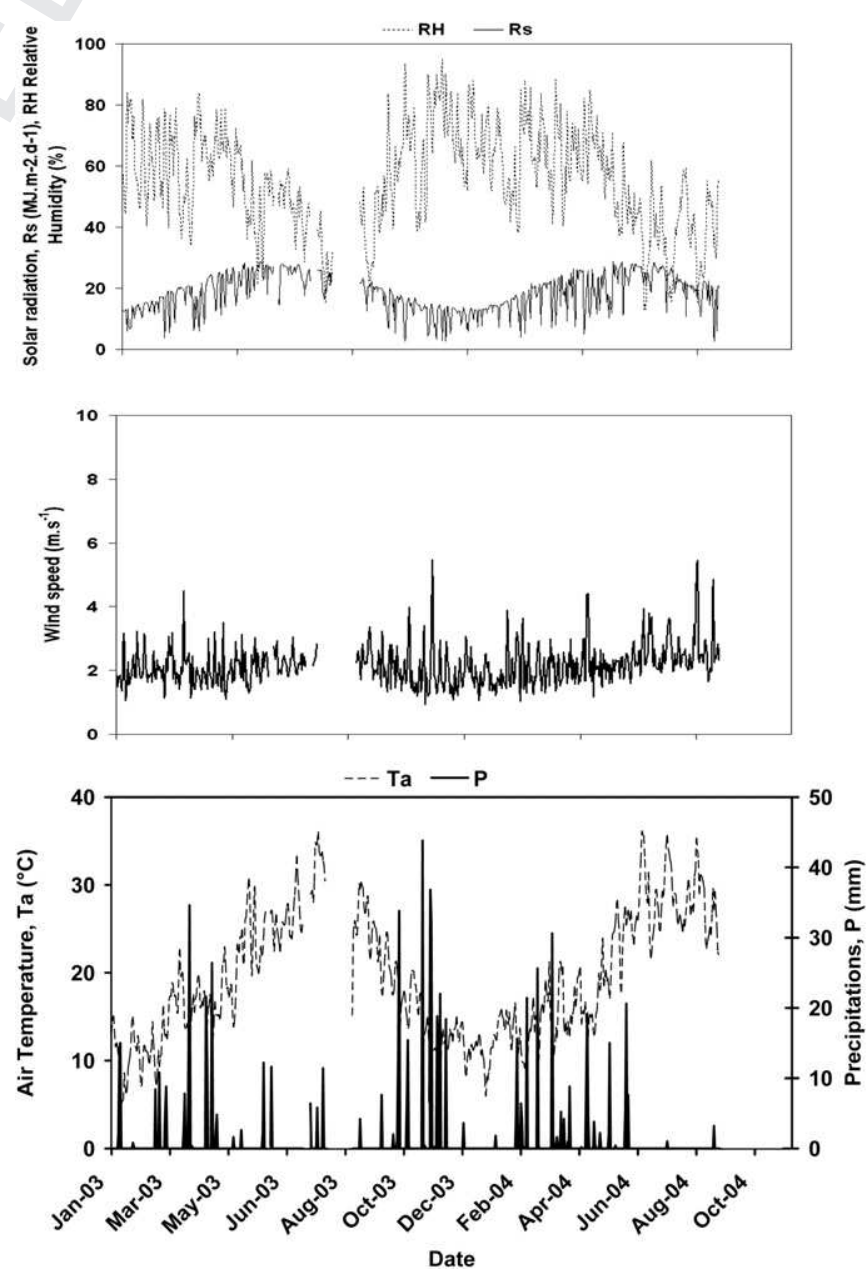

Fig. 2. Daily values of climatic parameters recorded by one station located in the Haouz plain (R3 in Fig. 1) during 2003-2004 years. Missing data in some days is due to problems with the power supply. 
none of the ground station of the Tensift network installed within the frame of the SudMed project is used to drive ALADIN such as forecast and stations measurements are independent.

\subsubsection{Yaqui Valley}

The Yaqui Valley is a large, flat agricultural area in the Northwest of Mexico. The total irrigated surface is about 255000 ha and the main crop (occupying more than $50 \%$ of the area) is winter wheat which grows from November to April every year. The climate of this region is semi-arid with an annual rainfall of around $350 \mathrm{~mm}$. The rainy season is from July to September (with about $70 \%$ of the annual rainfall) and there is a very dry season with almost no rainfall from March to June. The mean daily temperature ranges from about $17{ }^{\circ} \mathrm{C}$ in January to $31^{\circ} \mathrm{C}$ in summer (July-August). Half-hourly measurements of classical climatic data were collected over grass during 2004 using a standard micro meteorological weather station. Incoming solar radiation was measured with a BF2 Delta $\mathrm{T}$ radiometer, air temperature and humidity were measured at $2 \mathrm{~m}$ height with Vaisala HMP45C probes, and wind speed was measured at a $2 \mathrm{~m}$ with A100R anemometers (R.M. Young Company, USA). Further details of the field experimental setup can be found in Rodriguez et al. (2004).

\subsection{Reference evapotranspiration methods}

There are so many different methods for estimating reference evapotranspiration $\mathrm{ET}_{0}$ that it is often difficult to decide which one to use. In this context, we choose four methods for estimating $\mathrm{ET}_{0}$ which differ with the number of climatic parameters required: The first one is the FAO Penman-Monteith (FAO-PM) which is recommended by the Food and Agriculture Organization (FAO) as the standard method (Allen et al., 1998) to estimate $\mathrm{ET}_{0}$. It has been standardized by Allen et al. (2006). This method uses several climatic data such as: air temperature and relative humidity, solar radiation and wind speed (Eq. (1)). This method is taken as a comparator basis in this study. The second equation is the PT equation (Priestley and Taylor, 1972) which requires net radiation and air temperature data (Eq. (2)). The third one is the Mak method (Makkink, 1957) which requires solar radiation and air temperature (Eq. (3)). The last method is the HARG equation (Hargreaves and Samani, 1985) which only requires air temperature (Eq. (4)). These four methods are formulated as follows:

$\mathrm{ET}_{0 \_}$FAOPM $=\frac{0.408 \Delta\left(R_{\mathrm{n}}-G\right)+\gamma_{\frac{900}{T_{\mathrm{a}}+273}} u_{2}\left(e_{\mathrm{s}}-e_{\mathrm{a}}\right)}{\Delta+\gamma\left(1+0.34 u_{2}\right)}$

$\mathrm{ET}_{0-} \mathrm{PT}=0.408 \frac{\alpha \Delta\left(R_{\mathrm{n}}-G\right)}{\Delta+\gamma}$

$\mathrm{ET}_{0 \_}$Mak $=0.408 \frac{C_{\mathrm{m}} \Delta R_{\mathrm{s}}}{\Delta+\gamma}-0.12$

$\mathrm{ET}_{0-H A R G}=0.408 a\left(T_{\mathrm{a}}+17.8\right)\left(T_{\max }-T_{\min }\right)^{0.5} R_{\mathrm{a}}$

where $\mathrm{ET}_{0}$ is expressed in [mm/day]; $R_{\mathrm{S}}$ is the solar radiation [MJ/ $\mathrm{m}^{2} /$ day]; $R_{\mathrm{n}}$ and $R_{\mathrm{a}}$ are net radiation and extraterrestrial radiation respectively $\left[\mathrm{MJ} / \mathrm{m}^{2} /\right.$ day] computed as described by Allen et al. (1998); $G$ is the soil heat flux density $\left[\mathrm{MJ} / \mathrm{m}^{2} /\right.$ day], which is assumed to be 0 at daily time step; $T_{\mathrm{a}}$ is the air temperature at $2 \mathrm{~m}$ height $\left[{ }^{\circ} \mathrm{C}\right] ; u_{2}$ is the wind speed at $2 \mathrm{~m}$ height [m/s]; $e_{\mathrm{s}}$ and $e_{\mathrm{a}}$ are the saturation and actual vapor pressure $[\mathrm{kPa}]$ respectively; $\Delta$ is the slope of the vapor pressure curve at air temperature $\left[\mathrm{kPa} /{ }^{\circ} \mathrm{C}\right]$ and $\gamma$ is the psychrometric constant $\left[\mathrm{kPa} /{ }^{\circ} \mathrm{C}\right] . e_{\mathrm{s}}$ is computed as: $e_{\mathrm{S}}=\left(e^{0}\left(T_{\max }\right)+e^{0}\left(T_{\min }\right)\right) / 2$, where $e^{0}()$ is the saturation vapor function and $T_{\max }$ and $T_{\min }$ are the daily maximum and minimum air temperature respectively. The value 0.408 corresponds to the conversion factor from [MJ/m²/day] to $\mathrm{mm}$ /day. The parameters $\alpha$, $C_{\mathrm{m}}$ and $a$ that appear in Eqs. (2)-(4), respectively, are empirical constants. Their original values are $1.26,0.61$ and 0.0023 respectively (Allen et al., 1998; Makkink, 1957; McAneney and Itier, 1996; Priestley and Taylor, 1972).

\subsection{Statistical analysis}

The comparison between the three empirical methods (Eqs.

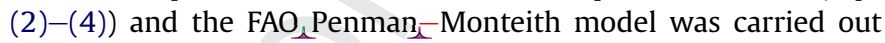
first using ground data. The comparison is evaluated using: (1) a linear regression equation $(Y=m X+c)$, through least square regression, between $\mathrm{ET}_{0}$ computed by $\mathrm{FAC}_{\mathbf{\alpha}}$ Penman-Monteith equation and $\mathrm{ET}_{0}$ estimated from the above mentioned three methods ( $m$ and $c$ are the slope and the intercept of the regression equation, respectively); (2) the coefficient of determination $\left(R^{2}\right)$; (3) the Root Mean Square Error (RMSE). In the case of a perfect correlation with no bias, $c=0$ and $m=1, R^{2}=1$ and $\mathrm{RMSE}=0$.

\section{Results and discussions}

\subsection{Evaluation of predicted and measured climatic data accuracy over Tensift}

The accuracy and quality of the measured weather data is evaluated over Tensift as the weather station network is quite dense ( 8 stations) with regard to the Yaqui Valley. The quality of meteorological measurement is simply evaluated by checking the overall consistency of the annual average of the climatic parameters (solar radiation, wind speed, air temperature and relative humidity) among different stations. Table 2 summarizes the annual average of the climatic variables over the 8 stations. The measurements appear consistent and coherent among different stations. Regarding to air temperature $\left(T_{\mathrm{a}}\right)$, the higher values are recorded in the Haouz plain (Agdal, Agafay, Chichawa, Grawa, Saada and R3) characterized by a semi-arid climate and the lower $T_{\mathrm{a}}$ is observed in the mountains (Okaimden and Armed). For relative humidity (RH), it is higher over irrigated areas (e.g. Agdal and Agafay stations) due to high evapotranspiration than in dry areas (mountain and bare soil). The measurements of wind speed $(U)$ are also consistent between different stations. The lower $U$ is encountered in the locations affected by the surrounding. The friction tends to decrease the wind as in the stations installed in tall vegetation (e.g. Agdal where the olive trees dominate). The higher $U$ is observed in the opened locations as the mountain (oukaimeden) and bare soil (R3, Chichaoua). For solar radiation $\left(R_{\mathrm{S}}\right)$, it is almost similar for all stations with a mean annual value of $19 \mathrm{MJ} /$ $\mathrm{m}^{2} /$ day. Additionally, the performance of solar radiation measurements is evaluated by comparing the measured net radiation $\left(R_{\mathrm{n}^{-}}\right.$ mes) against the estimated one $\left(R_{\mathrm{n}}-\mathrm{sim}\right)$ from FAO-56 (Eq. (40)). Fig. 3 displays the scatter plot between measured and FAO-predicted $R_{\mathrm{n}}$ over the stations where the measurements of $R_{\mathrm{n}}$ are available. This figure reveals a very good agreement (slope $=0.96$, with $R^{2}=0.94$ and $\mathrm{RMSE}=1.09 \mathrm{MJ} / \mathrm{m}^{2} /$ day) between the measured and FAO-predicted $R_{\mathrm{n}}$. In addition, the coefficient of variability (CV) defined as the ratio of the standard deviation to the mean value is calculated for each climatic parameter. It was equal 3.66, 31, 8.35 and $35.9 \%$ for $R_{\mathrm{S}}, T_{\mathrm{a}}, \mathrm{RH}$ and $U$, respectively. Clearly, variation in $U$ and $T_{\mathrm{a}}$ was larger than that in $R_{\mathrm{S}}$ and $\mathrm{RH}$.

As the measured weather data, the predicted ones by ALADIN were also evaluated before using them for estimating the spatial $\mathrm{ET}_{0}$. The quality of the ALADIN prediction in generating weather variables is evaluated by comparing the estimated climatic 
Table 2

Annual average of climatic parameters among the stations of study.

\begin{tabular}{|c|c|c|c|c|}
\hline Station & $\begin{array}{l}\text { Annual average of } R_{\mathrm{s}} \\
\left(\mathrm{MJ} / \mathrm{m}^{2} / \text { day }\right)\end{array}$ & $\begin{array}{l}\text { Annual average of } \\
T_{\mathrm{a}}\left({ }^{\circ} \mathrm{C}\right)\end{array}$ & $\begin{array}{l}\text { Annual average of } \\
\mathrm{RH}(\%)\end{array}$ & $\begin{array}{l}\text { Annual average of } \\
U(\mathrm{~m} / \mathrm{s})\end{array}$ \\
\hline Agdal & 18.74 & 19.46 & 60.20 & 0.80 \\
\hline Agafay & 19.30 & 18.24 & 60.07 & 1.06 \\
\hline Chichawa & 20.55 & 18.01 & 59.20 & 2.07 \\
\hline Graoua & 19.35 & 18.99 & 55.73 & 1.35 \\
\hline Saada & 18.05 & 19.69 & 58.76 & 1.48 \\
\hline R3 & 18.67 & 20.51 & 52.21 & 2.22 \\
\hline Okaimden & 19.61 & 4.61 & 45.59 & 2.53 \\
\hline Armed & 18.83 & 11.18 & 56.59 & 1.23 \\
\hline Max & 20.55 & 20.51 & 60.20 & 2.53 \\
\hline Min & 18.05 & 4.61 & 45.59 & 0.80 \\
\hline Mean & 19.14 & 16.34 & 56.04 & 1.59 \\
\hline CV (\%) & 3.66 & 31.00 & 8.35 & 35.90 \\
\hline
\end{tabular}

$R_{\mathrm{s}}$ : solar radiation (MJ/m²/day); $T_{\mathrm{a}}$ : air temperature $\left({ }^{\circ} \mathrm{C}\right)$; $\mathrm{RH}$ : relative humidity (\%); $U$ : wind speed $(\mathrm{m} / \mathrm{s})$.

$\mathrm{CV}$ : coefficient of variability (\%) defined as the ratio of the standard deviation to the mean value.

parameters with the ones measured over the Tensift basin. The climatic data recorded in equivalent ALADIN grid points to weather stations (Table 1, Fig. 1) are used. The values of climatic data in these equivalent grid points were calculated by weighting the values of climatic data recorded in each grid point (four grid points around the weather station) by using the bilinear interpolation (Arnaud and Emery, 2000). As mentioned above, the Tensift study area can be divided into a semi-arid climate region (the Haouz plain) and a sub-humid climate region (the high-Atlas mountains). Two stations were used for the local evaluation: one station (R3) characterizing the semi-arid climate in the plain, and another one (Armed) characterizing the sub-humid climate in the mountain. In this context, we compared the measured climatic parameters with the generated ones with ALADIN for two equivalent grid points to weather station (R3 and Armed, Fig. 1) during the year 2004. The associated statistical results are presented in Table 3. The ALADIN forecasts are in good agreement with the station measurements in terms of solar radiation $\left(R_{\mathrm{S}}\right)$ and air temperature $\left(T_{\mathrm{a}}\right)$ in both sites. The coefficient of determination $\left(R^{2}\right)$ and the slope are close to 1 especially for $T_{\mathrm{a}}$, and the RMSE are considered acceptable with regard to the average values. However, the comparison of the station and the forecasted values of relative humidity (RH) and wind speed $(U)$ is much more scattered (Table 3 ). The ALADIN model is known, in particular, to overestimate the wind speed in the bottom layers of the atmosphere due to the effect of surroundings (ground cover roughness, topography) that are not correctly taken into account in the model. Finally, the remaining error certainly also originates from the difference of spatial

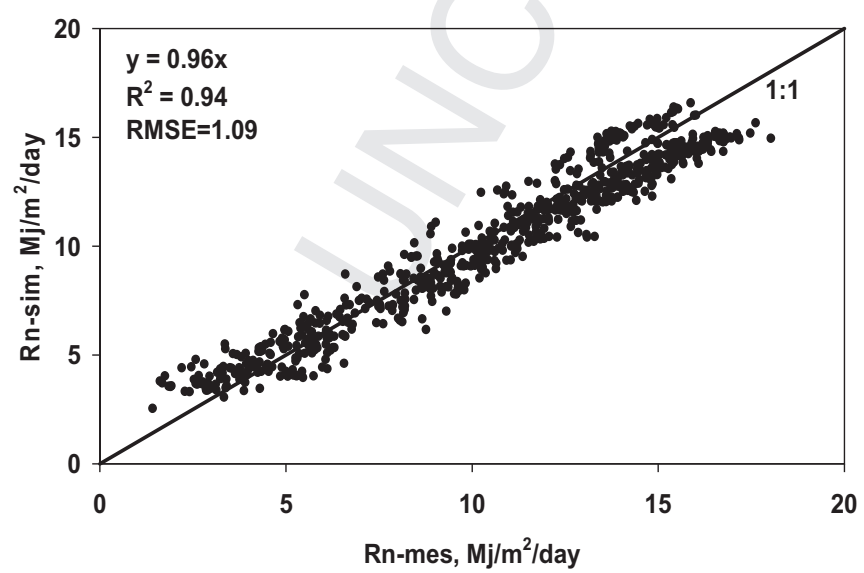

Fig. 3. Scatter plot between measured net radiation $\left(R_{\mathrm{n}}-\mathrm{mes}\right)$ and estimated one $\left(R_{\mathrm{n}}-\operatorname{sim}\right)$ by FAO-56 (Eq. (40)). representativeness between the ground station data and the ALADIN forecast grid point.

\subsection{Assessment of $E T_{0}$ estimation methods}

As mentioned above, the evaluation of the three methods (Eqs. (2)-(4)) is undertaken through the comparison with the FAO-PM equation. This evaluation was performed in two stages. In the first one, $\mathrm{ET}_{0}$ from the three empirical methods was computed with the original parameter values given above. In the second stage, $\mathrm{ET}_{0}$ was computed with locally calibrated parameter values. Based on the aridity index, the Tensift study area can be divided into a semi-arid climate region (the Haouz plain) and sub-humid climate region (the mountain). Two sites considered to be representative of each subregion were chosen to assess the performance of the three empirical methods. The first one is $\mathrm{R} 3$ which characterized the semi-arid climate in the Haouz plain. The second one is Armed situated in the Atlas mountain range, characterized by the sub-humid conditions (see Fig. 1 and Table 1 ).

\subsubsection{Assessment of the method performances without calibration}

Using the data collected in the year 2003 in the Haouz plain (station R3), daily evolution of $\mathrm{ET}_{0}$ values was calculated using the three empirical methods (Eqs. (2)-(4)). These values were then compared with those obtained using the FAO-PM method (Fig. 4). The statistical results are reported in 4 Table 4 . According to these results, the HARG method seems to be the best one to calculate $\mathrm{ET}_{0}$ in the Haouz plain (semi-arid climate). The coefficient of determination $\left(R^{2}\right)$ and the slope are close to 1 and the value of RMSE $=0.67 \mathrm{~mm} /$ day can be also considered acceptable with regard to the average value of $\mathrm{ET}_{0}(4.10 \mathrm{~mm})$, especially during the

Table 3

Statistical values of the comparison between observed climatic parameters and generated ones by ALADIN model at two grid points: dry with low altitude (R3) and humid with high altitude (Armed) during 2004.

\begin{tabular}{|c|c|c|c|c|c|c|c|c|}
\hline & \multicolumn{4}{|l|}{ R3 } & \multicolumn{4}{|l|}{ Armed } \\
\hline & $R_{\mathrm{s}}$ & $T_{\mathrm{a}}$ & RH & $U$ & $R_{\mathrm{S}}$ & $T_{\mathrm{a}}$ & RH & $U$ \\
\hline$n$ & 300 & 300 & 300 & 300 & 366 & 366 & 366 & 366 \\
\hline Average value & 18.67 & 20.51 & 52.21 & 2.22 & 18.83 & 11.18 & 56.59 & 1.23 \\
\hline Slope & 0.71 & 0.92 & 0.62 & 0.56 & 0.68 & 0.93 & 0.61 & 1.56 \\
\hline$Y$-intercept & 5.32 & 0.08 & 22.6 & 1.66 & 4.98 & 1.39 & 30.53 & 1.09 \\
\hline$R^{2}$ & 0.63 & 0.96 & 0.48 & 0.16 & 0.71 & 0.94 & 0.48 & 0.42 \\
\hline RMSE & 3.46 & 2.15 & 13.08 & 1.39 & 3.76 & 2.66 & 17.01 & 2.12 \\
\hline
\end{tabular}

$R_{\mathrm{s}}$ : solar radiation ( $\mathrm{MJ} / \mathrm{m}^{2} /$ day); $T_{\mathrm{a}}$ : air temperature $\left({ }^{\circ} \mathrm{C}\right) ; \mathrm{RH}$ : relative humidity (\%); $U$ : wind speed $(\mathrm{m} / \mathrm{s})$. Note that in the statistical analysis $X$ represents the observed climatic parameter and $Y$ the generated one by ALADIN model. 
summer (Fig. 4). This is in agreement with other studies (e.g. Hargreaves, 1994; Henggeler et al., 1996; Jensen et al., 1990). However, on some dates (DOY 71, March 12, 2003; DOY 263, September 20), a large difference between $\mathrm{ET}_{0}$ estimated by HARG and FAO-PM methods was observed. This is certainly due to the effect of wind speed which exceeded $3 \mathrm{~m} / \mathrm{s}$ on these days (Fig. 2). Indeed, Martınez-Cob and Tejero-Juste (2004) reported that when the wind speed is strong, the Hargreaves equation could underestimate $\mathrm{ET}_{0}$. In the same way, Berengena and Gavilan (2005) showed that, when the advection is severe, the Hargreaves equation tends to underestimate $\mathrm{ET}_{0}$ up to $25 \%$ for daily periods.

In contrast to HARG model, the performance of the two other methods (PT and Mak) was poor, the corresponding RMSE were 1.30 and $1.52 \mathrm{~mm} /$ day for PT and Mak, respectively (see Table 4 for other statistical analysis). However, Fig. 4 indicates that two distinct periods should be considered when using these methods, a dry period (when the daily mean air relative humidity is lower than
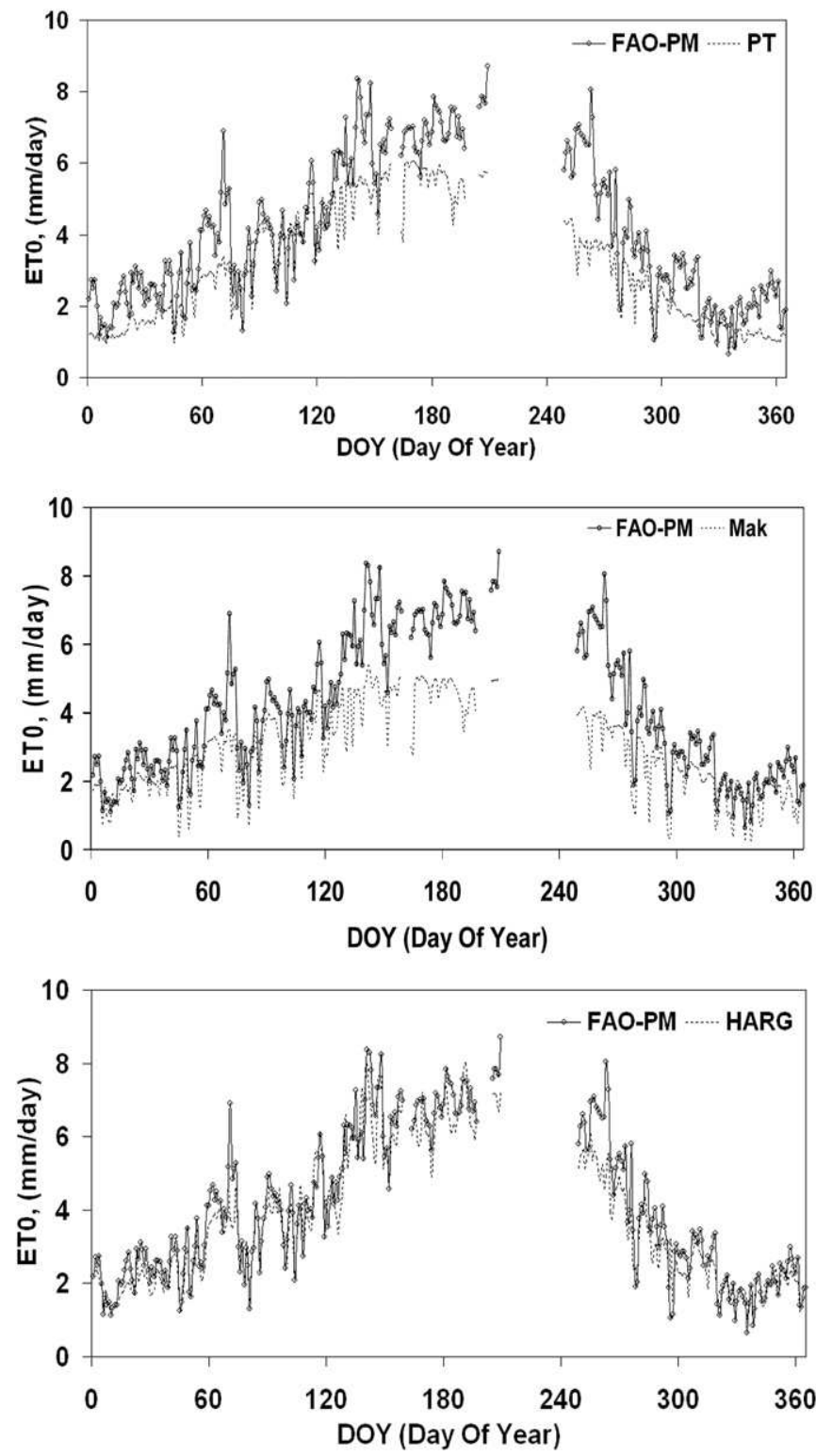

Fig. 4. Comparison between daily $\mathrm{ET}_{0}$ computed by the FAO-PM method against those by the three models (Eqs. (2)-(4)) with their original parameter values at the Haouz plain (R3 station) during 2003.

\section{Table 4}

Statistical values of the comparison between daily $\mathrm{ET}_{0}$ calculated by FAO-PM method against those obtained by the three empirical methods (PT, Mak and HARG), with their original parameter values at two regions in the Tensift basin: semi-arid (R3 station) and sub-humid (Armed station).

\begin{tabular}{|c|c|c|c|c|c|c|}
\hline \multirow[t]{3}{*}{ Statistics parameters } & \multicolumn{6}{|c|}{ Estimation method } \\
\hline & \multicolumn{3}{|l|}{ R3 } & \multicolumn{3}{|l|}{ Armed } \\
\hline & PT & Mak & HARG & PT & Mak & HARG \\
\hline$n$ & 315 & 315 & 315 & 366 & 366 & 366 \\
\hline Slope & 1.11 & 1.43 & 1.04 & 0.81 & 0.93 & 0.99 \\
\hline$Y$-intercept & 0.62 & -0.07 & 0.16 & 0.66 & 0.54 & 0.40 \\
\hline$R^{2}$ & 0.82 & 0.84 & 0.92 & 0.85 & 0.76 & 0.74 \\
\hline RMSE (mm/day) & 1.30 & 1.52 & 0.67 & 0.65 & 0.59 & 0.83 \\
\hline
\end{tabular}

$70 \%$ ) from DOY 140 to DOY 270 and the humid period (when RH is higher than 70\%) for the remaining days. It appears that the PT and Mak methods clearly underestimate the values of $\mathrm{ET}_{0}$ calculated using FAO-PM model during the dry period. Such behaviour can be explained by the fact that the values of $\alpha=1.26$ and $C_{\mathrm{m}}=0.61$, used in Eqs. (2) and (3), are only valid under humid conditions (Jensen et al., 1990; Priestley and Taylor, 1972). This explanation is confirmed by the results of the second period (when the cumulative rainfall was about $470 \mathrm{~mm}$ ). The statistical values (RMSE is equal to $0.97 \mathrm{~mm} /$ day for the PT method and $0.98 \mathrm{~mm} /$ day for the Mak) are consistent with those obtained for the HARG method. This is corroborated by other studies (e.g. Benson et al., 1992; Dugas and Ainsworth, 1983; Xiaoying and Erda, 2005).

To confirm the reliability of PT and Mak models for estimating daily $\mathrm{ET}_{0}$ with original parameter values $\left(\alpha=1.26\right.$ and $\left.C_{\mathrm{m}}=0.61\right)$ under sub-humid conditions, a comparison with the FAO-PM method is performed using climatic data collected in a sub-humid region situated in the high-Atlas mountain (Armed station, Table 1 and Fig. 1). Plotting daily values of $\mathrm{ET}_{0}$ estimated by FAO-PM against those estimated by both methods at this region (data not presented) revealed practically perfect agreement between the FAO$\mathrm{PM}$ and the estimates from the two other methods. The values of RMSE are 0.65 and $0.59 \mathrm{~mm} /$ day for the PT and Mak methods respectively. These values of RMSE are acceptable, given the average value of $\mathrm{ET}_{0}(3.22 \mathrm{~mm})$. Additional statistical results are presented in Table 4. The performance of the Hargreaves approach was lower in sub-humid conditions (RMSE $=0.83 \mathrm{~mm} /$ day) in comparison to the other methods. This is consistent with the results of other studies (Jensen et al., 1990; Xu and Singh, 2002) when they found that the HARG method tends to overestimate $\mathrm{ET}_{0}$ in a humid climate.

According to the above results, one can conclude that it is appropriate to use the HARG method without calibration to estimate $\mathrm{ET}_{0}$ in a semi-arid region (as far as the wind remains low). However, a calibration of two parameters $\left(\alpha\right.$ and $\left.C_{\mathrm{m}}\right)$ in the PT and Mak equations is needed, especially for the dry periods.

\subsubsection{Calibration and validation of the (PT) and (Mak) models} 3.2.2.1. Model calibration. The calibration of the parameters $\alpha$ and $C_{\mathrm{m}}$, figurate in Eqs. (2) and (3) was performed using data collected in the year 2003 in the Haouz plain (R3 station). The calibration procedure was based on minimizing the RMSE between $\mathrm{ET}_{0}$ values computed by each empirical equation and $\mathrm{ET}_{0}$ calculated by $\mathrm{FAO}-$ PM method.

Several studies have shown that the appropriate values for the parameter $\alpha$ varied considerably from humid region to arid and semi-arid regions. Values of 1.05 have been suggested in humid region by McNaughton and Black (1973). For an arid region, Jensen et al. (1990) and Steiner et al. (1991) have found a higher value of $\alpha$, up to 1.74 . Thus, we tried to adjust $\alpha$ with air relative humidity ( $\mathrm{RH}$, 
Table 5

Statistical values of the comparison between daily $\mathrm{ET}_{0}$ calculated by FAO-PM method against those obtained by the two empirical methods (PT, Mak), with the calibrated values of the parameters $\alpha$ and $C_{\mathrm{m}}$ (Eqs. (5) and (6)) at the Haouz plain (R3 station) during 2003.

\begin{tabular}{lcc}
\hline Statistics parameters & \multicolumn{2}{l}{ Estimation method } \\
\cline { 2 - 3 } & PT & Mak \\
\hline$n$ & 315 & 315 \\
Slope & 0.84 & 0.97 \\
$Y$-intercept & 0.85 & 0.31 \\
$R^{2}$ & 0.92 & 0.92 \\
RMSE (mm/day) & 0.70 & 0.60 \\
\hline
\end{tabular}

$\%)$, which is an indicator of regional climate (humid or dry). In this context, the appropriate values of $\alpha$ have been determined for each interval of relative humidity with steps of $10 \%$. The linear regression obtained between $\alpha$ and (RH) was:
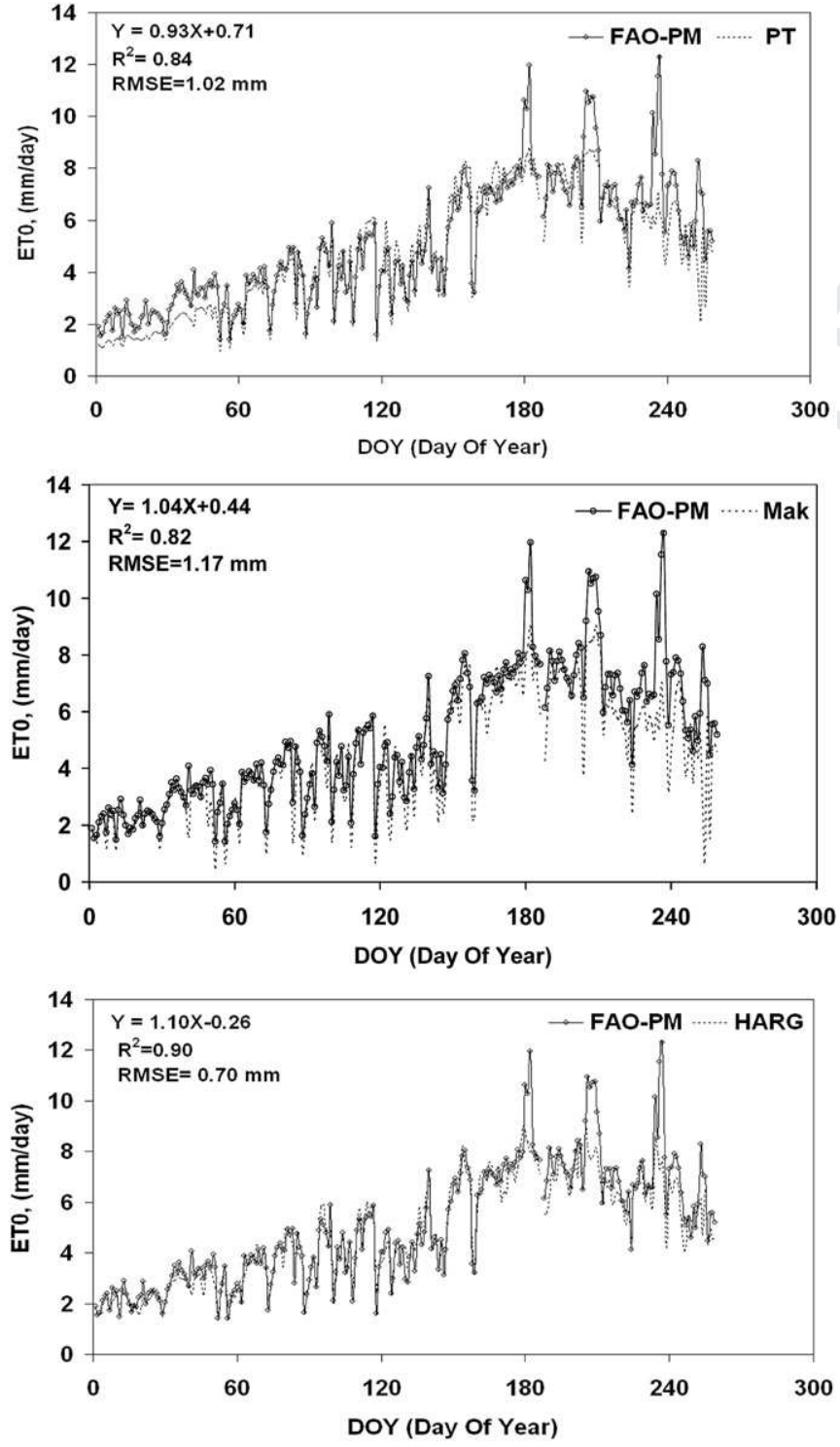

Fig. 5. Comparison between the values of $\mathrm{ET}_{0}$ calculated by FAO-PM method and those by the three empirical methods at the Haouz plain (R3 station), using the calibrated values of the parameters $\alpha$ and $C_{\mathrm{m}}$ for PT and Mak models, and the original value of the parameter $a$ for HARG method during 2004. The relevant statistical parameters are included in figures.
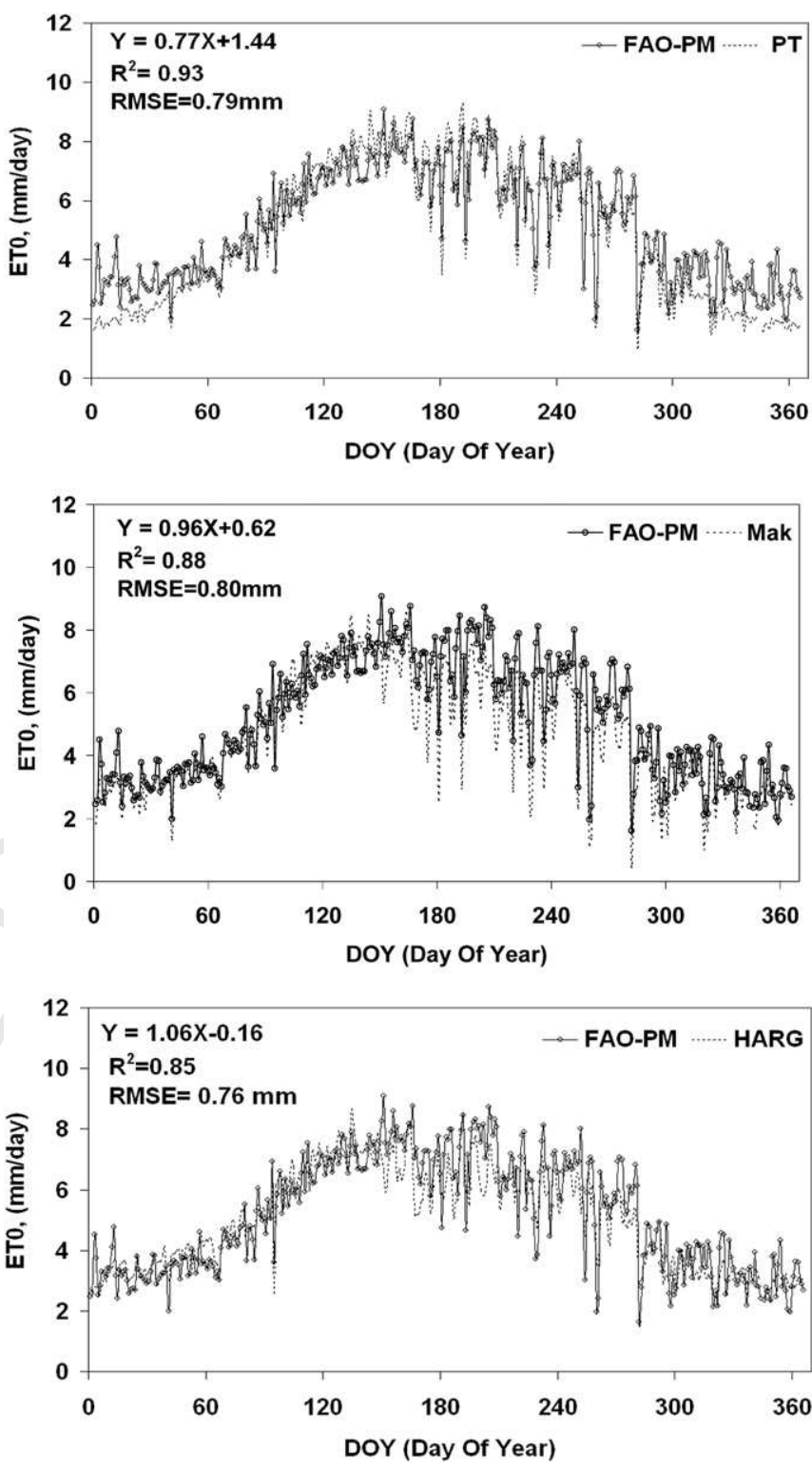

Fig. 6. Comparison between the values of $\mathrm{ET}_{0}$ calculated by FAO-PM method and those by the three empirical methods at the Yaqui Valley (Northwest Mexico), using the calibrated values of the parameters $\alpha$ and $C_{\mathrm{m}}$ for PT and Mak models, and the original value of the parameter $a$ for HARG method during 2000. The relevant statistical parameters are included in figures.

$\alpha=-0.014 \mathrm{RH}+2.33, \quad R^{2}=0.98$

It can be noted that this equation estimates $\alpha=1.26$ when daily mean $\mathrm{RH}=76 \%$ and $\alpha=1.74$ when $\mathrm{RH}=42 \%$. This indicates that the calibration of $\alpha$ (Eq. (5)) could be applied in many areas depending on the climate (arid, humid...).

Similarly, the Makkink constant $C_{\mathrm{m}}$ was adjusted by a linear regression to $(\mathrm{RH})$ :

$C_{\mathrm{m}}=-0.0062 \mathrm{RH}+1.15, \quad R^{2}=0.96$

This calibration of the Makkink constant $C_{\mathrm{m}}$ is similar to that done by Doorenbos and Pruitt (1977), where their Radiation method of FAO-24 was multiplied by a correction that was based on $\mathrm{RH}$ and on daytime wind speed.

After the calibration of two parameters $\alpha$ and $C_{\mathrm{m}}$, the RMSE was reduced to 0.70 and $0.60 \mathrm{~mm} /$ day (Table 5) for the PT and Mak 

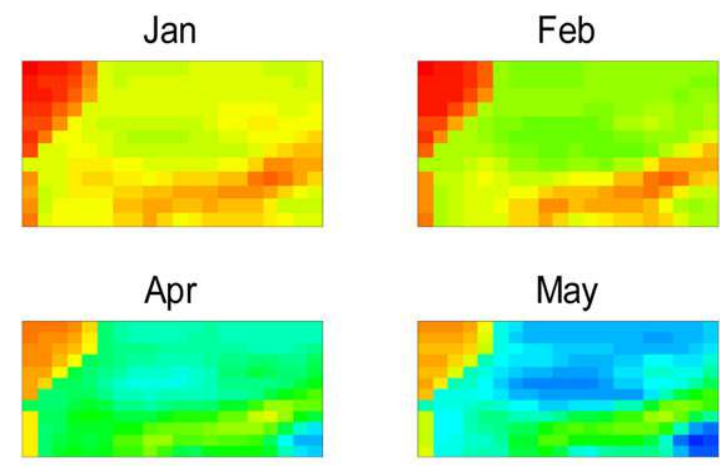

Jul
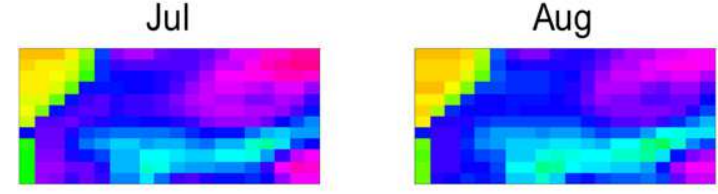

Oct

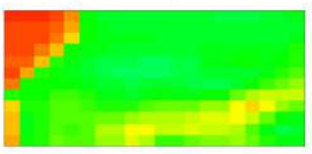

Nov

Feb

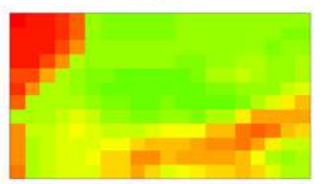

May

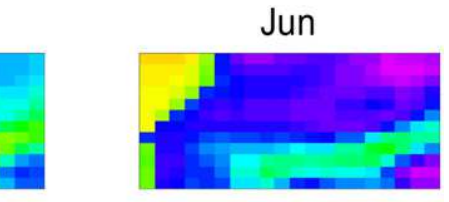

Sep

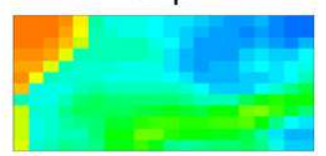

Dec

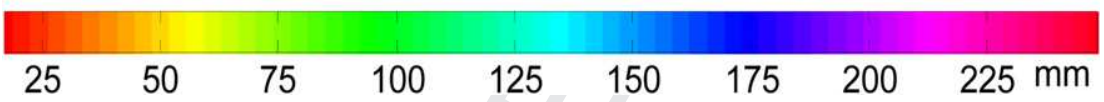

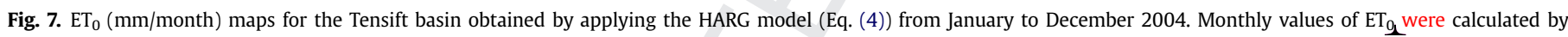
summing the daily values.

methods respectively. This means an improvement of $46 \%$ and $60 \%$ of the values obtained with respect to the original values of $\alpha$ and $C_{\mathrm{m}}$ (Table 4).

3.2.2.2. Model validation. The data collected during 2004 from the experimental site of the Haouz plain (R3 station) were used together with additional data set collected over the experimental site of the Yaqui Valley (Northwest Mexico) for model validation purposes.

By using the calibrated parameters (Eqs. (5) and (6)) and the original value (0.0023) of the parameter $a$, daily values of $\mathrm{ET}_{0}$ calculated by the PT, Mak and HARG models are compared to those obtained by the FAO-PM method. The performance of each method is shown for the Haouz plain in Fig. 5, as well as the associated statistical parameters. As shown in the previous paragraph, the HARG method always presents the best agreement to the FAO results. The coefficient of determination $\left(R^{2}\right)$ and the slope are close to 1 , the value of RMSE $=0.70 \mathrm{~mm} /$ day can be also considered very acceptable with respect to average value of $\mathrm{ET}_{0}(5.07 \mathrm{~mm})$ (Fig. 5). Also both calibrated methods (PT and Mak) estimate $\mathrm{ET}_{0}$ with an acceptable accuracy, the values of RMSE are 1.02 and $1.17 \mathrm{~mm} /$ day respectively for the PT and Mak methods. In some days (DOYs 180-183, 206-209, 234-237 and 253-254), the values of $\mathrm{ET}_{0}$ obtained by the three methods are lower than those of FAO-PM method. This was due to the high values of $\hat{\text { wind }}$ speed which exceeded $3 \mathrm{~m} / \mathrm{s}$ on these days (see Fig. 2), which lead to high values for the aerodynamic term (advection) that is one of the main differences between the FAO-PM method and other empirical equations (Berengena and Gavilan, 2005).

For the Yaqui Valley site (Fig. 6), the validation also provides an accuracy estimate of $\mathrm{ET}_{0}$ by three models. The obtained values of RMSE, 0.79, 0.80 and $0.76 \mathrm{~mm} /$ day for the PT, Mak and HARG methods respectively, are considered relatively acceptable with regard to the average value of $\mathrm{ET}_{0}$ which reached about $5.17 \mathrm{~mm} /$ day (Fig. 6). Also the HARG method is the best one to estimate $\mathrm{ET}_{0} \mathbf{Q 8}$ over this other semi-arid region.

According to these results, it can be concluded that the HARG model is the most reliable method for estimating $\mathrm{ET}_{0}$ over both semi-arid test sites (Tensift basin and the Yaqui Valley) when the availability of climatic variable is limited and when wind speed not exceeded $3 \mathrm{~m} / \mathrm{s}$.

\subsection{Spatially distributed modelling of $E T_{0}$}

The spatial variation of $\mathrm{ET}_{0}$ over the Tensift region is analyzed thanks to the ALADIN model forecast data. The good performance of the HARG model at the local scale together with the accurate estimation of air temperature by the ALADIN model, which is the main input of the HARG method, lead us to choose this model for estimating the spatial distribution of $\mathrm{ET}_{0}$ with regard to the Mak and PT methods. In addition, the spatial estimation of $\mathrm{ET}_{0}$ by the HARG model is compared to the FAO-PM method using ground based measurements of climatic parameters. Indeed, the FAO-PM is expected to be penalized by the strong discrepancy between ALADIN forecast and measured climatic data in terms of wind and air humidity.

Fig. 7 shows the cumulative monthly $\mathrm{ET}_{0}(\mathrm{~mm} / \mathrm{month})$ maps for the whole Tensift basin by applying the HARG model to each grid point of the ALADIN model from January to December 2004. This figure exhibits a coherent spatial and temporal variation of $\mathrm{ET}_{0}$. Temporally, the $\mathrm{ET}_{0}$ appears to be highest in the summer (June-August), ranging from 45 to $230 \mathrm{~mm} / \mathrm{month}$ during the peak period for air temperature, and the smallest $\mathrm{ET}_{0}$ in November-January (16-68 $\mathrm{mm} / \mathrm{month})$. Spatially, the higher $\mathrm{ET}_{0}$ is observed in the low altitude (like Haouz plain), and lower $\mathrm{ET}_{0}$ is encountered in the mountain when the altitude is high and air temperature is low. It should be mentioned that lower values of $\mathrm{ET}_{0}$ 
are observed over the mountain in winter when the snow covering is high and precludes from evaporation. Such maps of $\mathrm{ET}_{0}$ could be used by decision makers to assist in water management and irrigation scheduling at regional scale.

In order to go further in the evaluation of the spatial distribution of $\mathrm{ET}_{0}$ predicted by the HARG model, the HARG $\mathrm{ET}_{0}$ is compared to $\mathrm{ET}_{0}$ calculated by the FAO-PM method from the meteorological data measured by the weather stations for 12 months at the eight stations (Table 1 ) with the spatially modelled results for the corresponding months at the corresponding equivalent grid points (Fig. 8). The associated statistical parameters are included in this figure. It should be mentioned that due to power supply problems, some data of $\mathrm{ET}_{0}$ estimated by FAO-PM were missing in some days and the data during the corresponding month were not available. The coefficient of determination $\left(R^{2}=0.92\right)$ and the slope (1.09) are close to 1 . The value of RMSE $=16.01 \mathrm{~mm} / \mathrm{month}$ can be also considered acceptable relative to the mean values of cumulative monthly $\mathrm{ET}_{0}(120 \mathrm{~mm} / \mathrm{month})$. It is clear from Fig. 8 that the correlation is best when the monthly value of $\mathrm{ET}_{0}$ was below $160 \mathrm{~mm}$. When the monthly $\mathrm{ET}_{0}$ was above this value, the HARG method underestimates $\mathrm{ET}_{0}$ similarly to the local scale evaluation of the method. As already stated above, this is certainly due to the advection term that is not taken into account in the HARG method.

Finally, the FAO-PM method is run using the model forecast data. The scatter plot between $\mathrm{ET}_{0}$ calculated by the FAO-PM method from the measured meteorological data and the calculated one using the forecast data (not shown) revealed practically an overestimation of $\mathrm{ET}_{0}$ by the FAO-PM method with regard to the HARG method together with a strong scattering on the stations where the difference between measured and generated climatic parameters is high. For information, the statistical characteristics of the linear fit are as follows: slope $=1.10$, intercept $=-17.42$, $R^{2}=0.85$ and $\mathrm{RMSE}=21 \mathrm{~mm} / \mathrm{month}$. By comparing those relevant statistical parameters with those obtained when using HARG method (Fig. 8), it is clear that this latter performs best although its simplicity. A good performance of the HARG method over the studied semi-arid sites has been expected, because it was originally developed for semi-arid environments. Several studies have shown that the HARG method provides good estimates of $\mathrm{ET}_{0}$ under semiarid conditions in different countries, as done by Vanderlinden et al. (1999), Martınez-Cob and Tejero-Juste (2004) and Berengena and Gavilan (2005) in Spain, by Dinpashoh (2006) for

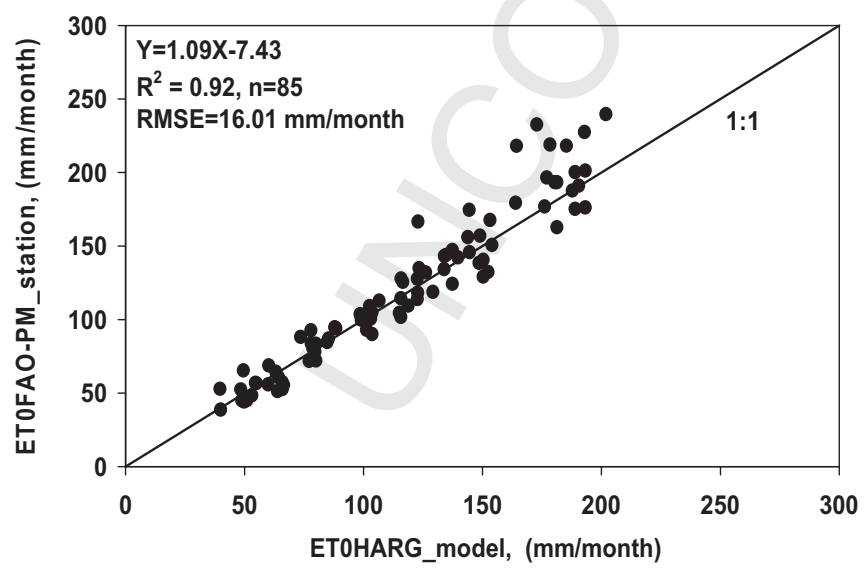

Fig. 8. Scatter plot between the cumulative monthly $\mathrm{ET}_{0}$ estimated by FAO-PM method from the meteorological data measured by the weather stations and HARG model estimated $\mathrm{ET}_{0}$ from the meteorological data provided by ALADIN model at eight weather stations (Table 1) during 2004. Note that some cumulative monthly $\mathrm{ET}_{0}$ estimated by FAO-PM are not available due to problems with the power supply of weather stations.
Iran, and by Jensen et al. (1990), Choisnel et al. (1992), Hargreaves (1994) and Henggeler et al. (1996) for different locations.

As a conclusion, HARG method provides a simple yet robust alternative to the complex, physically-based, FAO-PM method when the availability of climatic variables is limited and in particular, concerning the wind speed.

\section{Summary and conclusions}

The FAO-PM equation has a sound physical background and has proven to accurately estimate $\mathrm{ET}_{0}$. Nevertheless, a drawback which limits its widespread use is that it requires measurements of several meteorological variables: air temperature and relative humidity, solar radiation and wind speed. The lack of the availability of these variables in most parts of the world has led to the development of simpler $\mathrm{ET}_{0}$ estimation equations requiring only a few climatic variables which are most likely to be available worldwide. In this context, the main objectives of this paper were to test, calibrate and validate, in semi-arid regions of central Morocco (Tensift basin) and Northwest Mexico (Yaqui Valley), three methods computing $\mathrm{ET}_{0}$ based on solar radiation (PT and Mak) and temperature (HARG) against the standard FAO-PM method. The results showed that the HARG method, with its standard constant value $(0.0023)$, worked quite well under moderate wind conditions $(<3 \mathrm{~m} / \mathrm{s})$ while the performance of the other two empirical methods was poor except in humid conditions. A local calibration of the two parameters $\alpha$ and $C_{\mathrm{m}}$ which appear respectively in the PT and Mak equations is needed especially for the dry periods.

Air relative humidity $(\mathrm{RH})$ appeared to affect the accuracy of the PT and Mak equations. An adjustment of two parameters $\alpha$ and $C_{\mathrm{m}}$ with $\mathrm{RH}$ by using the data collected in the semi-arid region of Tensift basin was proposed. Thus, the original coefficients 1.26 and 0.61 should be replaced by a linear regression with RH (Eqs. (5) and (6)). These locally adjusted coefficients produced a significant improvement in the equations performance. The Root Mean Square Error (RMSE) was reduced to 0.70 and $0.60 \mathrm{~mm} /$ day for the PT and Mak methods respectively, which meant an improvement of $46 \%$ and $60 \%$ compared to the values obtained without calibration (1.30 and $1.52 \mathrm{~mm} /$ day). A further validation of the adjusted coefficients $\alpha$ and $C_{\mathrm{m}}$ was performed using another semi-arid site in the Yaqui Valley (Northwest Mexico) where the estimates of $\mathrm{ET}_{0}$ produced by these methods were found to be very reliable.

To overcome the difficulty associated with the scarcity of weather stations measuring the needed meteorological parameters for $\mathrm{ET}_{0}$ estimates, the possibility of using climatic data generated with numerical weather prediction model (ALADIN) has been assessed over the Tensift basin. The evaluation of the quality of this model in generating weather variables showed that the ALADIN model estimates accurately air temperature, which is the main input of the HARG method. This leads us to choose this method for estimating the spatial and temporal distribution of $\mathrm{ET}_{0}$. This approach is of particular interest since it not only allowed us to overcome the problem of the lack of weather data, but it also able to predict water needs with a forecast lead time of few days, which is of great importance for irrigation water managers. Another interest of this research paper consists of identifying which the most reli- $\mathbf{Q}$ able method for estimating $\mathrm{ET}_{0}$ can be used in hydrological models. This will certainly improve the performance of this type of models as reported by Oudin et al. (2005) when they showed that the 1 lumped rainfall-runoff model works well in simulating streamflow when using a simple temperature-based $\mathrm{ET}_{0}$ instead of the Penman-type model.

Finally, it should be noted that this study was based on a limited data set. Further study including longer series of climatic data is 
desirable for considering climate variability and for improving the reliability of the proposed calibrations.

However, it should be noted that this study was based on the analysis of a limited data set. A more comprehensive study, including longer series of data, is advisable to improve the reliability of the proposed calibrations.

\section{Acknowledgements}

This work was performed as a part of research supported by the European Union 5th Framework through two INCO-MED Projects: SUDMED/IRRIMED (http://www.irrimed.org/) and PLEIADeS (http:// www.pleiades.es/). The referees and the editor comments are gratefully acknowledged.

\section{References}

Allen, R.G., Pereira, L.S., Raes, D., Smith, M., 1998. Crop Evapotranspiration-Guidelines for Computing Crop Water Requirements. In: Irrigation and Drain, Paper No. 56. FAO, Rome, Italy, 300 pp.

Allen, R.G., Pruitt, W.O., Wright, J.L., Howell, T.A., Ventura, F., Snyder, R., Itenfisu, D., Steduto, P., Berengena, J., Yrisarry, J.B., Smith, M., Pereira, L.S., Raes, D., Perrier, A., Alves, I., Walter, I., Elliott, R., 2006. A recommendation on standardized surface resistance for hourly calculation of reference $\mathrm{ET}_{0}$ by the FAO56 Penman-Monteith method. Agric. Water Manage. 81, 1-22.

Amatya, D.M., Skaggs, R.W., Gregory, J.D., 1995. Comparison of methods for estimating REF-ET. J. Irrig. Drain. Eng. 121 (6), 427-435.

Arnaud, M., Emery, X., 2000. Estimation et interpolation spatiale, méthodes déterministes et méthodes géostatistiques. Editions Hermès Sciences Publications.

Benson, V.W., Potter, K.N., Bogusch, H.C., Goss, D., Williams, J.R., 1992. Nitrogen leaching sensitivity to evapotranspiration and soil water storage estimates in EPIC. J. Soil Water Conserv. 47 (4), 334-337.

Berengena, J., Gavilan, P., 2005. Reference evapotranspiration estimation in a highly advective semiarid environment. J. Irrig. Drain. Eng. ASCE 131 (2), 147-163.

Blaney, H.F., Criddle, W.D., 1950. Determining Water Requirements in Irrigated Areas from Climatologically and Irrigation Data. USDA (SCS) TP 9648.

Chehbouni, A., Escadafal, R., Duchemin, B., Boulet, G., Simonneaux, V., Dedieu, G., Mougenot, B., Khabba, S., Kharrou, $H$, Maisongrande, $\mathrm{P}$, Merlin, $\mathrm{O}$., Chaponnière, A., Ezzahar, J., Er-Raki, S., Hoedjes, J., Hadria, R., Abourida, A., Cheggour, A., Raibi, F., Boudhar, A., Benhadj, I., Hanich, L., Benkaddour, A., Guemouria, N., Chehbouni, A.H., Lahrouni, A., Olioso, A., Jacob, F., Williams, D.G. Sobrino, J., 2008. An integrated modelling and remote sensing approach for hydrological study in arid and semi-arid regions: the SUDMED programme. Int. J. Remote Sens. 29 (17 \& 18), 5161-5181.

Choisnel, E, de Villele, O., Lacroze, F, 1992. Une approche uniformisée du calcul de l'évapotranspiration potentielle pour l'ensemble des pays de la Communauté Européenne. Publication EUR 14223. Office des Publications Officielles des Communautés Européennes, Luxembourg.

De Bruin, H.A.R., Stricker, J.N.M., 2000. Evaporation of grass under non-restricted soil moisture conditions. Hydrol. Sci. 45 (3), 391-406.

Dinpashoh, Y., 2006. Study of reference crop evapotranspiration in I.R. of Iran. Agric. Water Manage. 84, 123-129.

Doorenbos, J., Pruitt, W.O., 1977. Crop Water Requirements. In: FAO Irrigation and Drainage Paper No. 24. Food and Agriculture Organization of the United Nations, Rome, 144 pp.

Droogers, P., Allen, R.G., 2002. Estimating reference evapotranspiration under inaccurate data conditions. Irrig. Drain. Syst. 16, 33-45.

Dugas, W.A., Ainsworth, C.G., 1983. Agroclimatic Atlas of Texas. Part 6. Potential Evapotranspiration. Texas Agric. Exp. Stn. Mp-1543, 82 pp.

Déqué, M., Dreveton, C., Braun, A., Cariolle, D., 1994. The ARPEGE-IFS atmosphere model: a contribution to the French community climate modelling. Clim. Dyn. 10, 249-266.

Hargreaves, G.H., 1994. Defining and using reference evapotranspiration. J. Irrig. Drain. Eng. 120 (6), 1132-1139.

Hargreaves, G.H., Samani, Z.A., 1985. Reference crop evapotranspiration from temperature. Appl. Eng. Agric 1 (2), 96-99.
Henggeler, J.C., Samani, Z., Flynn, M.S., Zeitler, J.W., 1996. Evaluation of various evapotranspiration equations for Texas and New Mexico. In: Camp, C.R. Sadler, E.J., Yoder, R.E. (Eds.), Proceedings of the International Conference on Evapotranspiration and Irrigation Scheduling, San Antonio, TX, USA, 3-6 November 1996, pp. 962-967.

Hussein, M., Al-Ghobari, 2000. Estimation of reference evapotranspiration for southern region of Saudi Arabia. Irrig. Sci. 19 (2), 81-86

Jensen, M.E., Burman, R.D., Allen, R.G., 1990. Evapotranspiration and irrigation water requirements. In: ASCE Manuals and Reports on Engineering Practice, No. 70 332.

Jensen, D.T., Hargreaves, G.H., Temesgen, B., et al., 1997. Computation of $\mathrm{ET}_{0}$ under non ideal conditions. J. Irrig. Drain. Eng. 123 (5), 394-400.

Kashyap, P.S., Panda, R.K., 2001. Evaluation of evapotranspiration estimation methods and development of crop coefficients for potato crop in a sub-humid region. Agric. Water Manage. 50 (1), 9-25.

Makkink, G.F., 1957. Testing the Penman formula by means of lysimeters. J. Inst. Water Eng. 11, 277-288.

Martınez-Cob, A., 2002. Evaluación de métodos de cálculo de la evapotranspiración de referencia diaria y mensual en Aragón. ITEA 23, 126-132.

Martınez-Cob, A., Tejero-Juste, M., 2004. A wind-based qualitative calibration of the Hargreaves $\mathrm{ET}_{0}$ estimation equation in semiarid regions. Agric. Water Manage. 64 (3), 251-264.

McAneney, K.J., Itier, B., 1996. Operational limits to the Priestley-Taylor formula Irrig. Sci. 17, 37-43.

McNaughton, K.G., Black, T.A., 1973. A study of evapotranspiration from a Douglasfir forest using the energy balance approach. Water Resour. Res. 9 (6) 1579-1590.

Monteith, J.L., 1965. Evaporation and environment. In: 19th Symposia of the Society for Experimental Biology 19. University Press, Cambridge, pp. 205-234.

Oudin, L., Hervieu, F., Michel, C., Perrin, C., Andreassian, V., Anctil, F., Loumagne, C., 2005. Which potential evapotranspiration input for a lumped rainfall-runoff model?: part 2-towards a simple and efficient potential evapotranspiration model for rainfall-runoff modelling. J. Hydrol. 303, 290-306.

Penman, H.L., 1948. Natural evaporation from open water, bare soil, and grass. Proc R. Soc. Lond. A193, 116-140.

Priestley, C.H.B., Taylor, R.J., 1972. On the assessment of surface heat flux and evaporation using large scale parameters. Mon. Weather Rev. 100, 81-92.

Ritchie, J.T., 1985. A user-oriented model of the soil water balance in wheat. In: Fry, E., Atkin, T.K. (Eds.), Wheat Growth and Modeling. NATO-ASI Series. Plenum Publishing Corp., pp. 293-305.

Rodriguez, J.C. Duchemin, B., Hadria, R. Watts, C., Khabba, S., Boullet, G., Garatuza, J., Chehbouni, A., Lahrouni, A., Palacios, E., 2004. Wheat yield estimation using remote sensing and the STICS model in the semi-arid valley of Yaqui, Mexico. Agronomie 24, 295-304.

Saeed, M., 1986. The estimation of evapotranspiration by some equations under hot and arid conditions. Trans. ASAE 29 (2), 434-438.

Smith, M., 2000. The application of climatic data for planning and management of sustainable rainfed and irrigated crop production. Agric. For. Meteorol. 103, 99-108.

Steiner, J.L., Howell, T.A., Schneider, A.D., 1991. Lysimetric evaluation of daily potential evaporation models for grain sorghum. Agron. J. 83, 240-247.

United Nations Environment Programme, 1997. World Atlas of Desertification. In: Middleton, N., Thomas, D. (Eds.), second ed., 182 pp.

Utset, A., Farré, I., Martínez-Cob, A., Cavero, J., 2004. Comparing Penman-Monteith and Priestley-Taylor approaches as reference-evapotranspiration inputs for modeling maize water-use under Mediterranean conditions. Agric. Water Manage. 66, 205-219.

Vanderlinden, K., Romero, A., Reina, D., Giráldez, J.V., 1999. Evaluación del método de Hargreaves en 16 estaciones completas de Andalucía. In: Proceedings of the XVII Congreso Nacional de Riegos, Murcia, Spain, 11-13 May 1999, pp. 92-99.

Walter, I.A., Allen, R.G., Elliott, R., Jensen, M.E., Itenfisu, D., Mecham, B., Howell, T.A. Snyder, S., Brown, P., Echings, S., Spofford, T., Hattendorf, M., Cuenca, R.H. Wright, J.L., Martin, D., 2000. ASCE'S standardized reference evapotranspiration equation. In: Proceedings of 4th National Irrigation Symposium, ASAE, Phoenix (Arizona, USA), November 14-16, 2000.

Williams, J.R., Jones, C.A., Kiniry, J.R., Spanel, D.A., 1989. The EPIC crop growth model. Trans. ASAE 32 (2), 497-511.

Xiaoying, L., Erda, L., 2005. Performance of the Priestley-Taylor equation in the semiarid climate of north China. Agric. Water Manage. 71, 1-17.

Xu, C.Y., Singh, V.P., 2002. Cross comparison of empirical equations for calculating potential evapotranspiration with data from Switzerland. Water Resour Manage. 16, 197-219. 